\title{
Is the hospital-park future of the sustainable hospital architecture?
}

\author{
Irina Bulakh*, Margaryta Didichenko, Olena Kozakova, Olena Chala, and Gelena Kovalska \\ Kyiv National University of Construction and Architecture, 31 Povitroflotskyi Ave., Kyiv, 03680, Ukraine
}

\begin{abstract}
The article deals with important issues of the ecological approach to the health care facilities design within the general world's attention to the problem of sustainable development of the urban environment. Taking as the example the innovative foreign experience of implemented projects of medical institutions, as well as design, competitive and conceptual proposals revealed the latest idea of coexistence and harmonization of natural and man-made worlds within the medical environment that meets the challenges and needs of the XXI century. It is the concept of the hospital-park, that synthetically combines the architectural environment, natural environment, as well as man-made oasis and creates the basis for emergent results both in the medical field and in the need for a neat attitude to our planet. The article reveals the possibilities of designing a hospital-park of different stories and in different initial conditions: in a dense urban environment with a minimum size of the construction site, in suburban and peripheral areas of the city.
\end{abstract}

\section{Introduction}

Architecture is gradually changing along with the society development, its changing perceptions of beauty, strength, usefulness, as well as the growing need for comfort, aesthetics, the ideal environment. For a long time, the architecture of health care facilities was perceived and, accordingly, mechanically designed exclusively as a kind of technically necessary shell to ensure the treatment of the depersonalized population. (Fig. 1).

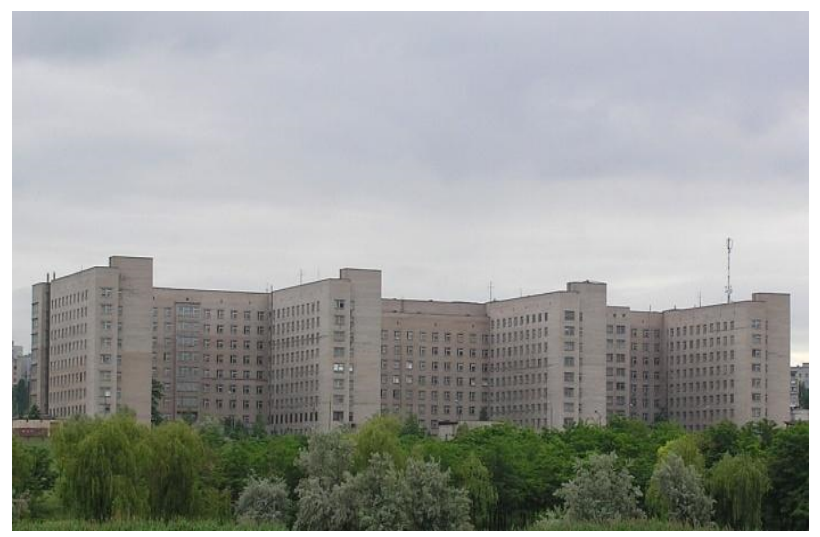

Fig. 1. "Tysiachka" - hospital №2, Kryvyi Rih, Ukraine. Source: https://krmisto.gov.ua/ua/hospitals/2.html.

This approach appeared due to the acute and rapid need in wast amount of medical institutions widely. In particular, this was the case in the last century in the post-
Soviet countries. All over this area there were "cloned" typical projects of medical institutions, integrated into the urban environment with huge industrial and panel arrays without regional, cultural and aesthetic connection with "genius loci" and urban context (Fig. 2).

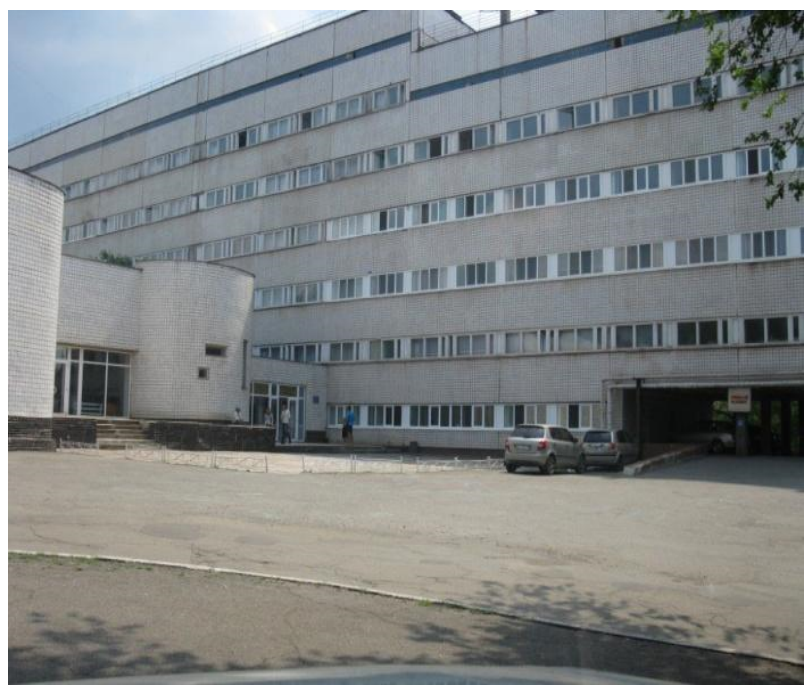

Fig. 2. City Clinical Maternity Hospital №1, Kryvyi Rih, Ukraine. Source: https://info.1kr.ua/place-4367.html

Do we have the right to condemn this large-scale approach that prevailed in the 20th century? No. At that time, this approach allowed to solve the important medical care issues for the majority of the population of the Soviet Union. Thanks to the mass and economic

\footnotetext{
* Corresponding author: bulakh.iv@knuba.edu.ua; irabulakh81@gmail.com
} 
industrial design and construction approach, Ukraine has received an extensive urban network of various health care facilities, which continue to perform their functions, accepting the harsh challenges and trials of global pandemics and epidemics.

The main issue is that the acquisition of sovereignty in Ukraine provoked political and oligarchic clan "internecine wars", which for decades froze the attention to improving, modernizing, updating and developing the architecture of health care facilities. Many Ukrainian hospitals are in a condition that not only does not meet sanitary and other requirements, but also threatens the health and lives of patients and staff (Fig. 3, Fig. 4, Fig. 5, Fig. 6).

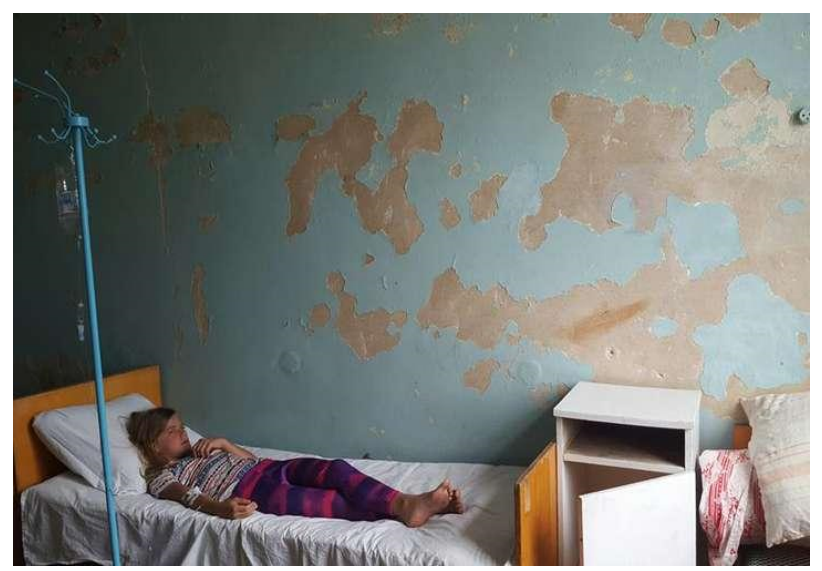

Fig. 3. The ward in Henichesk Central District Hospital, Henichesk (a resort in the south Ukraine), Ukraine. Source: https://www.umoloda.kiev.ua/number/3190/218/113989/

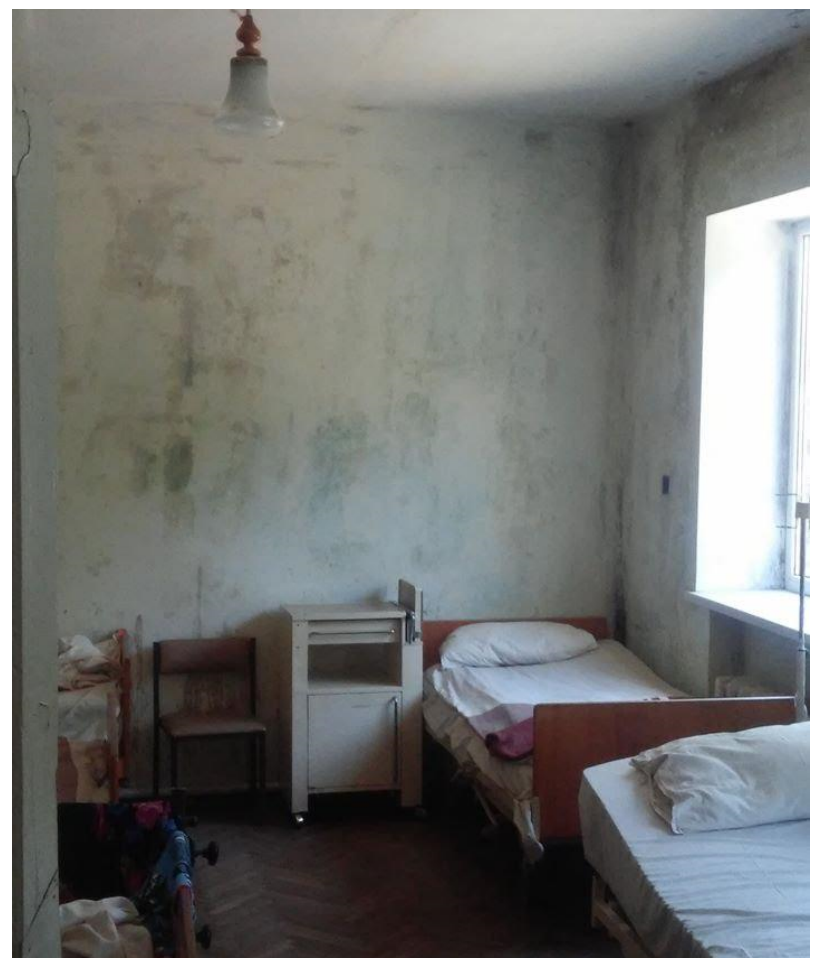

Fig. 4. The ward in a Mostyska regional hospital, Mostyska, Ukraine.

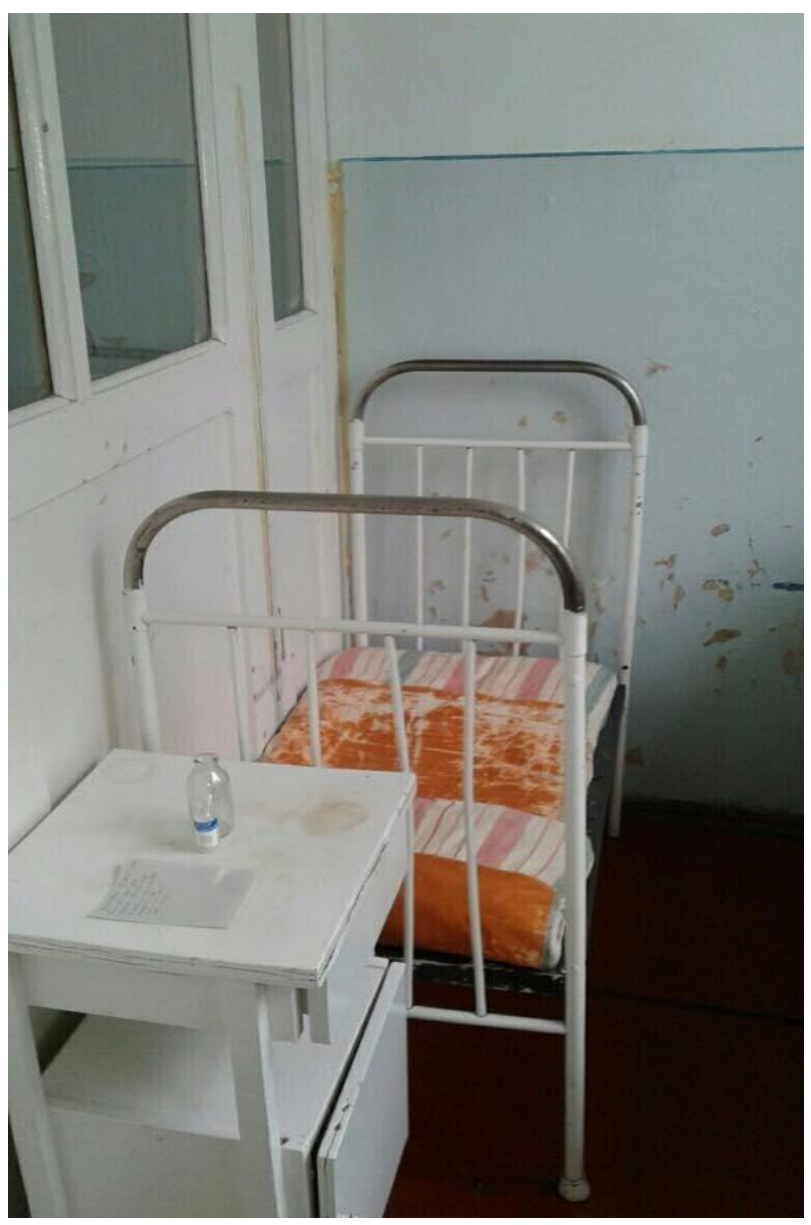

Fig. 5. Lutsk Infectious Diseases Hospital, Lutsk, Ukraine. Source: https://lutsk.rayon.in.ua/news/29452-v-oblasniiinfektsiinii-likarni-zanepad-i-antisanitariia

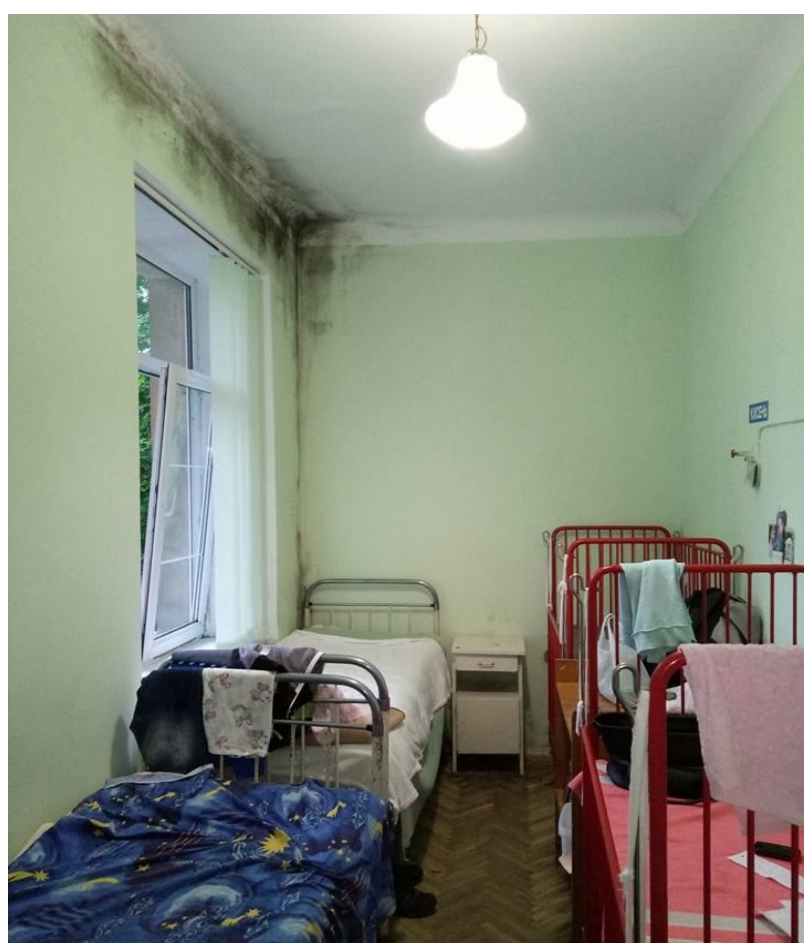

Fig. 6. Wards for newborns in surgery of Lviv Okhmatdyt, Lviv, Ukraine. Source: https://lviv.molbuk.ua/picture-of-theday/283-palaty-dlya-novonarodzhenykh-u-khirurgiyilvivskogo-okhmatdytu-urazheni-chornoyu-cvillyu-foto.html 
Despite the fact of the total ignoring of the problems and issues of compliance of domestic medical architecture with world standards for 30 years already, the powerful and somehow the world's best "machine" continued to work, inertially moving down from its pedestal. Nowadays, in 2021, we are frantically approaching the foot of a new "rock" that embodies all the latest advances in health care and which the world's leading countries have gradually, step by step, overcome with a long-term state plan for medical development and carrying out periodic reforms in the medical field.

\section{How the hospitals are designed in the world leading countries?}

The architecture of health care facilities needs to be upgraded. Hopefully, this is already happening in developed countries. Today hospitals are more likely fivestar hotels with all the services rather than ordinary hospitals, for instance in the United States, Germany, France, England, Singapore, Hong Kong, the United Arab Emirates, and others [1]. The attitude towards a patient, who is now a key figure and not a faceless person for calculating statistical indicators of the beds need, that used to be, has changed. The "hotel" hospitals have various ranges of different restaurants, cafes, bank branches, entertainment, shops, and other public functions, which we use in our everyday life (Fig. 7) [24]. A sick person can and should live a full life.
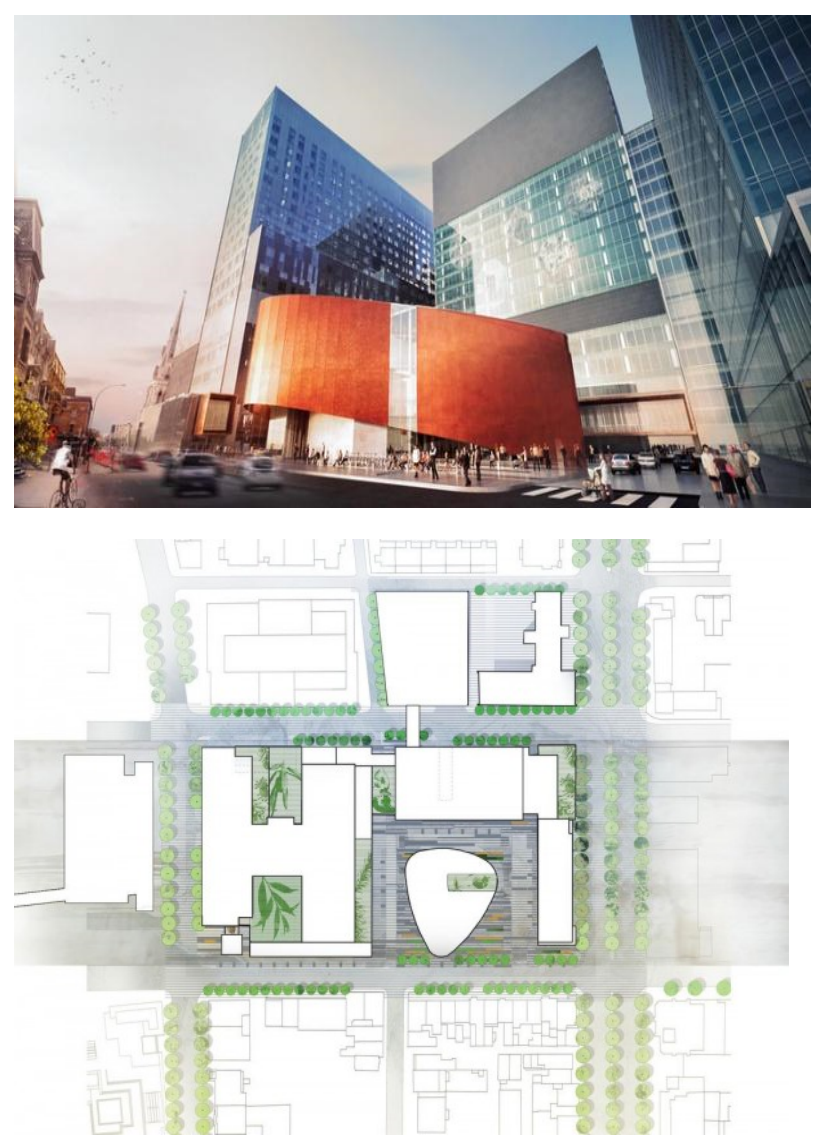

Fig. 7. University of Montreal Hospital Center, Canada. Source: http://healthcare.wsp-pb.com/portfolio/centrehospitalier-de-luniversite-de-montreal-chum/?portfolioCats $=42$
Cutting-edge hospitals are megastructural multifunctional medical complexes that have a variety of departments and are usually able to provide all types of medical care services for all age groups of patients. Hospital facilities occupy a large total area, that in some cases can range from 150-300 thousand sq.m. The dense urban environment of megapolises with the lack of free space forces the expansion of existing and historic hospitals significantly in the height dimension. As the result, the new buildings are often difficult to distinguish from the rest of the high-rise public buildings (Fig. 8) [5].
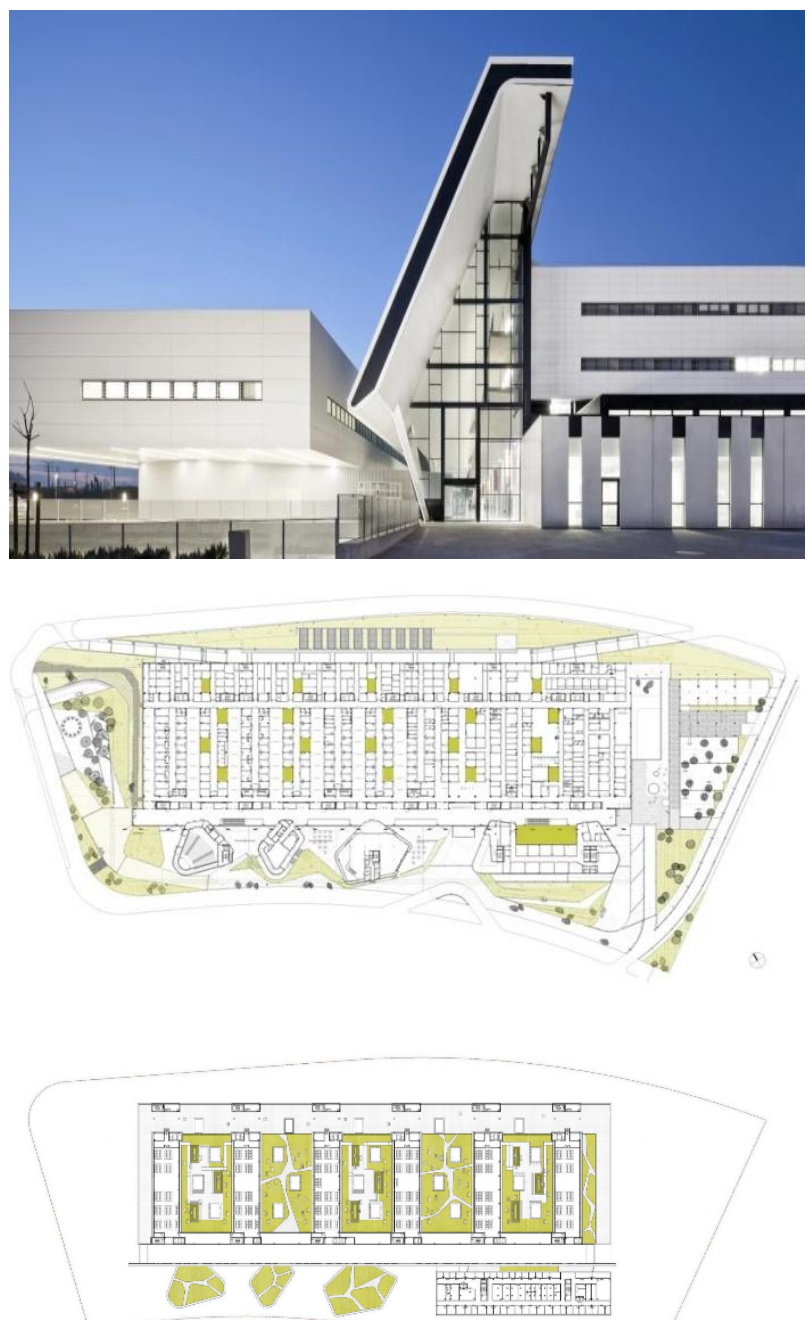

Fig. 8. University Hospital Sant Joan de Reus, Reus, Spain. Source: https://archello.com/project/university-hospital-santjoan-de-reus

Recently the architectural design of hospital complexes pays significant attention to the organization of public spaces and the interior and adjacent hospital area for the communication between visitors, patients, and staff of the medical institution (Fig. 9) [6]. Architects are actively implementing fascinating multi-story and linear atriums, courtyards, which in addition to public spaces provide natural lighting for the hospital buildings. It should be noted that the patient's ability to independently choose the communication level with society is extremely 
important. Communicating with others the sick person feels needed, fully-fledged, and not lonely.

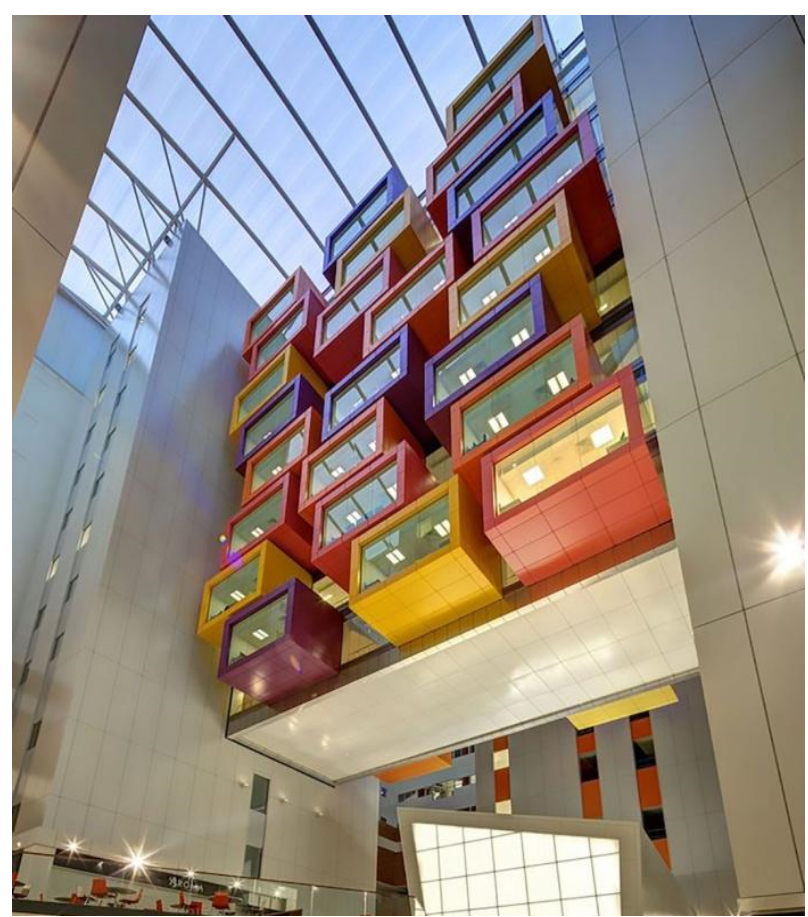

Fig. 9. Queen Elizabeth University Hospital (QEUH), Glasgow, Scotland. Source: http://healthcare.wsppb.com/portfolio/queen-elizabeth-university-hospital-glasgowuk/

\section{Future hospitals, which are being developed today}

The globe is very contrasting. Simultaneously, many hospitals continue to operate, despite they often do not even have basic living conditions such as sewerage, water supply, and heating. And alongside humanity is working on mega-complex projects of extraterrestrial hospitals. There are many examples of dilapidated buildings with the sign "hospital". Quite often it's difficult to name these buildings as "hospitals". Unfortunately, there are a lot of such destroyed examples all over Ukraine and in rural areas of other post-Soviet states (Fig. 10).

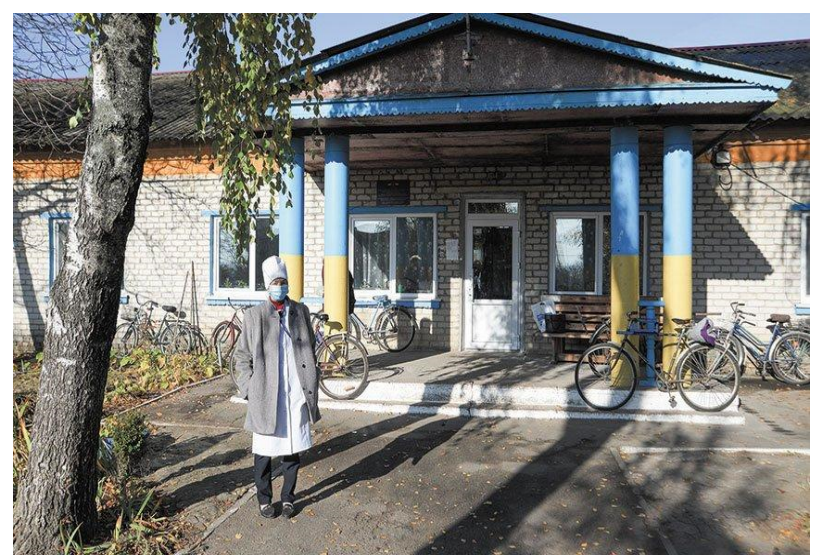

Fig. 10. Rural hospital Voronkiv village, Ukraine.
At the same time, across the planet in the United Arab Emirates a multi-million project and the opening of the world's first space hospital Emirates Space Hospital, located in Dubai is taking place (Fig. 11, Fig. 12) [7, 8]. The Innovative Hospital of the Future will focus on the UAE Centennial 2071 program and the National Space Program. The hospital will be an example of how telemedicine can be used in the future. Not only in the "Earth" hospitals but also in the space ones. The testing of the first mobile hospital units is planned to be conducted on Mars. The treatment at the Emirates Space Hospital will be carried out using the latest nanorobots, which are able to independently find diseased cells in the astronauts' bodies and cure them [9].

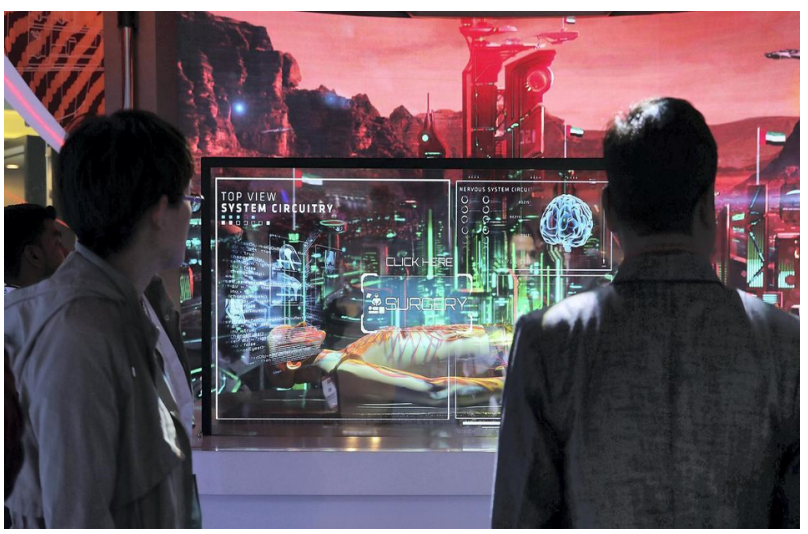

Fig. 11. Project of Emirates Space Hospital, Dubai, UAE / Mars. Source:

https://www.thenationalnews.com/uae/health/space-clinicbeing-developed-to-treat-emirati-astronauts-1.700621

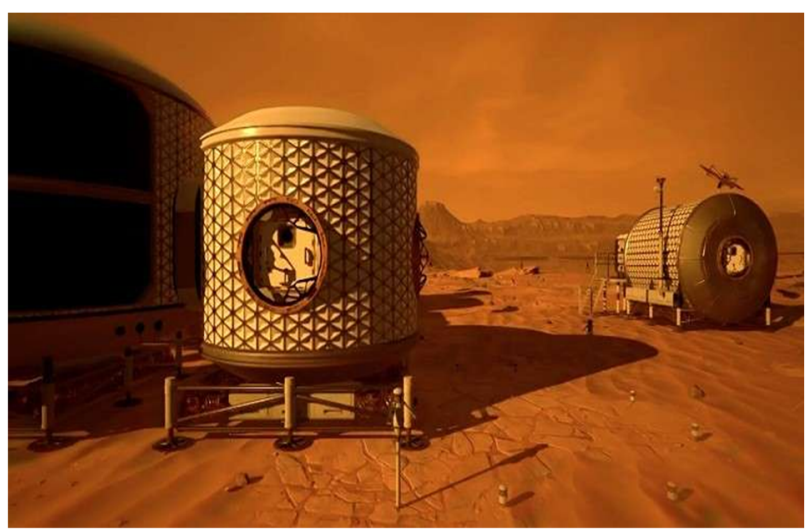

Fig. 11. Medical capsule project to send to Mars, Emirates Space Hospital, Dubai, UAE / Mars. Source: https://dubaiofw.com/mars-science-city-launched/

Besides the project of the future hospital in the UAE, there are already terrestrial and "extraterrestrial" (in terms of architecture and technology) medical facilities that actively use robotization of medical processes, automatic movement of patients and staff, transfer of laboratory materials, and other means by pneumatic pipes, automation of constant control of the main vital signs of patients from mobile devices, etc. (Fig. 12, Fig. 13) [10]. All these and other achievements have allowed bringing the country's medicine to the world top ten list according to the published rating of the analytical agency Bloomberg [11]. 


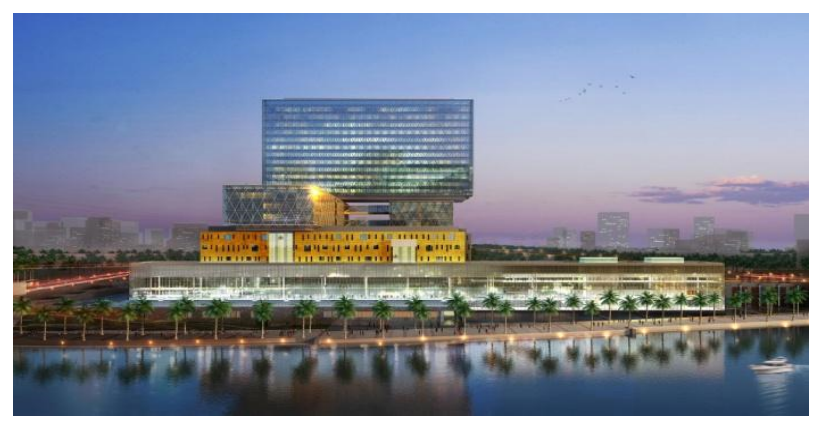

Fig. 12. Cleveland Clinic Abu Dhabi, Abu Dhabi, UAE. Source: https://consultqd.clevelandclinic.org/cleveland-clinicabu-dhabi-performs-the-uaes-first-full-heart-transplant/

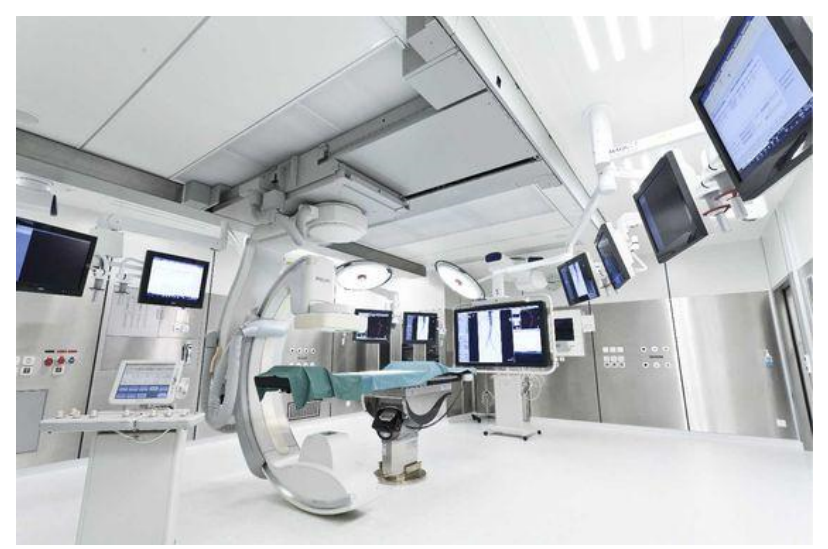

Fig. 13. Robotic operating room. Source:

https://www.orlandohealth.com/content-hub/the-wonders-andbenefits-of-robotic-surgery

\section{The sustainable development of the health care institutions' architecture}

The climate is transforming, and finally, humanity has turned its attention to this issue. At least it's trying to do it. Everyone urges the need for an ecological approach in design, caring attitude to the natural environment, energysaving, and sustainable development and everywhere [1223]. In recent decades, the world has held numerous conferences, symposia, international programs, and projects [24]. The problem and the question of the need for sustainable development in architecture affect the whole variety of typological objects of the design activities of architects. Including the segment engaged in the design of health care facilities [25-32].

The current hospitals should not be excluded from the list of energy efficient facilities. They should be designed in accordance with the latest environmental principles and guidelines of sustainable architecture. There are already implemented innovative projects of medical complexes, which should serve as a model for us over the globe. Even in a dense urban environment, on a fairly compact site architects designed and implement a hospital that integrated both the full range of advanced "green" technologies: starting from the full use of regional climate and construction sites (individual aerodynamic spatial and planning structure of the building), ending with the "standard" elements (reuse of rain and used water, solar panels, active and passive insolation, natural ventilation, smart home technology, microclimate through landscaping of roofs and numerous outdoor terraces, as well as many other environmental techniques) (Fig. 14) [33-35].

This design approach has many advantages. Along with the maximum energy autonomy level, compliance with the principles of sustainable development for the future of our planet is achieved by the architects, who managed to create an individual and recognizable artistic icon of the building. This aspect is also very important because the feelings and emotions that the architectural environment evokes significantly affect the process and duration of a sick person's recovery [36]. It should be stated, that the direction of research of the development of their own healing properties of the architectural environment and medical buildings is quite new, but is promising and necessary.
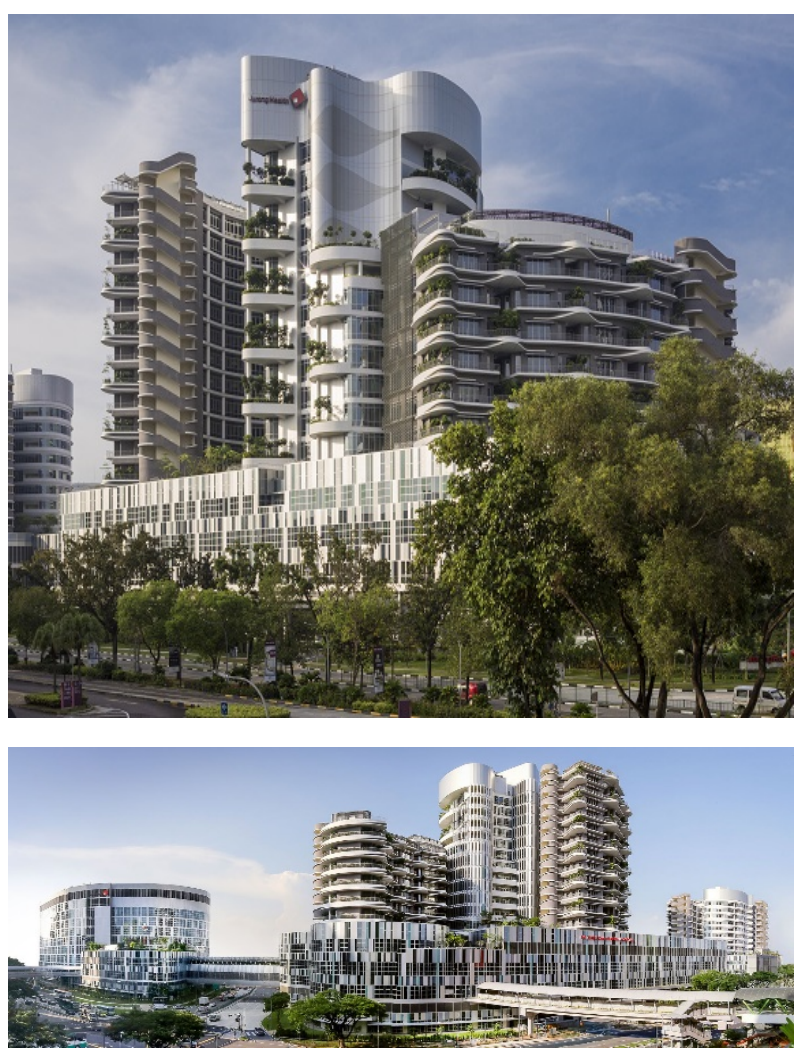

Fig. 14. The hospital complex Ng Teng Fong (NTFGH) \& Jurong (JCH) in the urban area, Singapore. Source: https://www.wsp.com/en-MY/projects/ng-teng-fong-generalhospital-singapore

Not fewer than the innovative architectural design approach, which directly affects the development of projects' environmental potential of health care institutions the active integration of the natural environment into the internal and external spaces of medical complexes plays their roles. The latest implemented projects, as well as those that are at the design stage, many competitive and exploratory conceptual developments of hospital buildings allow characterizing this area as the design of the "hospital park". 


\section{5 "Hospital-park" - a proposal for sustainable development of hospital architecture}

The hospital-park is a synthesis of a medical building and the natural environment, which involves the active integration of landscaping both in the interior and in the hospital's area improvement. If we talk about the external environment of hospitals, the considerable attention of foreign architects to landscape design over the past decade should be acknowledged. A striking example of the artificial formation of nature in a rather small hospital area is the Lady Cilento Children's Hospital by Conrad Gargett, South Brisbane, Australia (Fig. 15, Fig. 16) [37, 38].
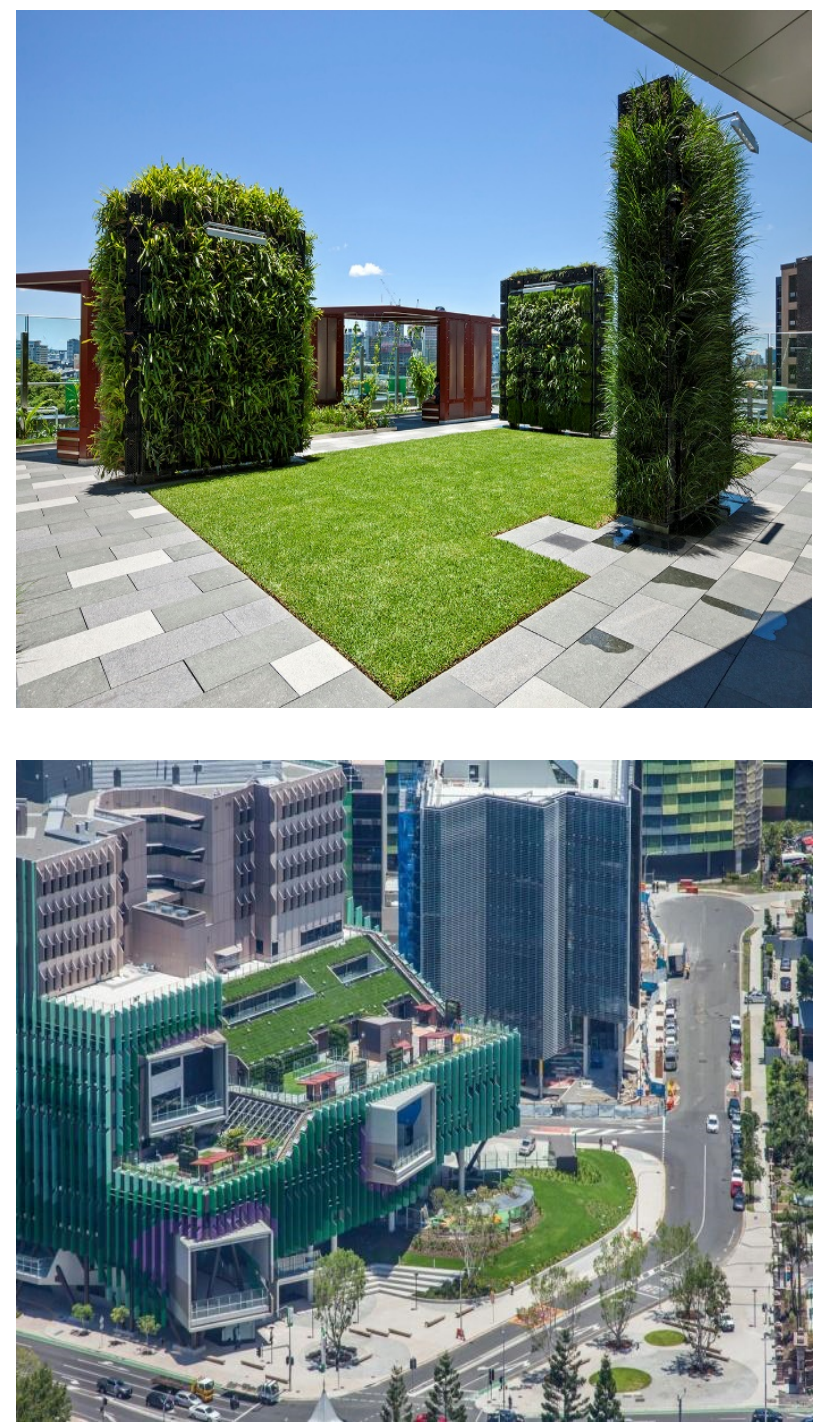

Fig. 15. General view of the Lady Cilento Children's Hospital by Conrad Gargett, South Brisbane, Australia. Source: https://www.archdaily.com/595827/new-lady-cilento-childrens-hospital-lyons-conrad-gargett

In order to maximize the area of the hospital site, the elements of a "man-made nature" were integrated by the architect's decision of plantings and lawns on the terraces, roof, and even used vertical landscaping of the hospital walls. As a result, despite the almost complete absence of its own free territory, the hospital formed a small oasis in the middle of the "stone jungle" of a dense urban environment.

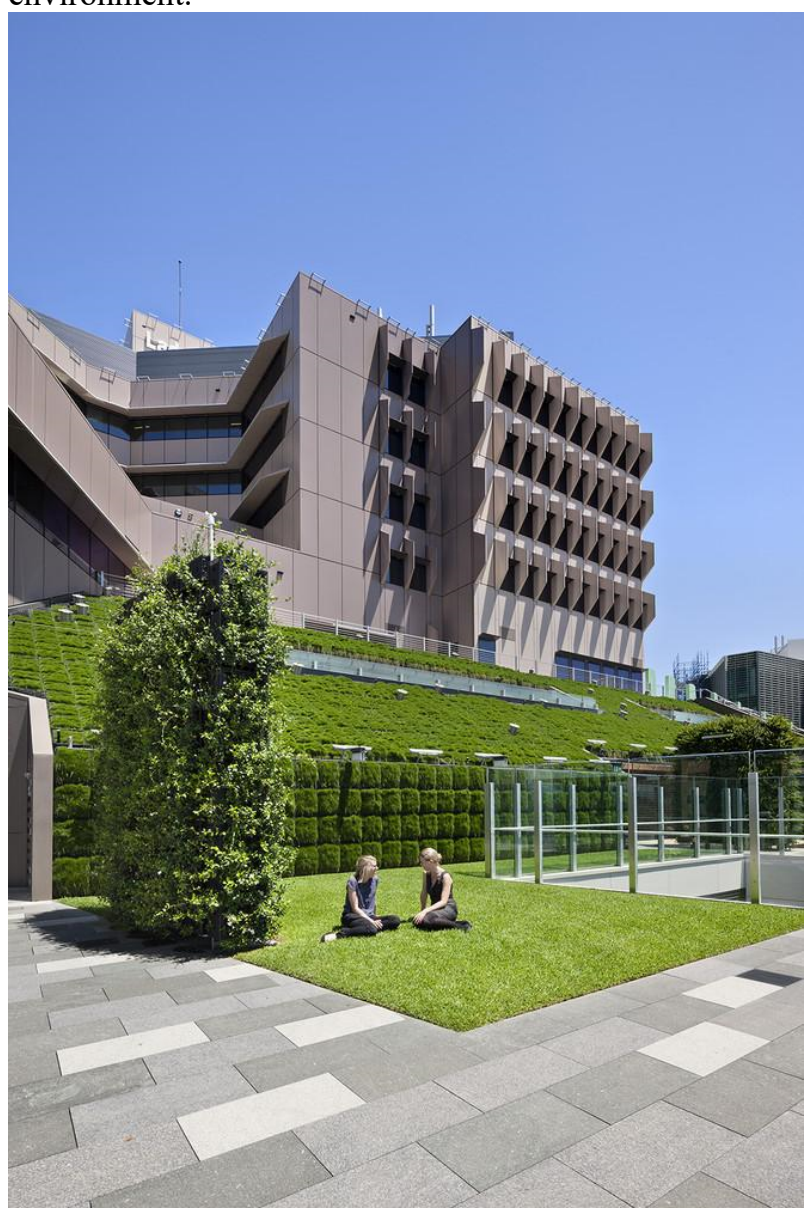

Fig. 16. The Lady Cilento Children's Hospital by Conrad Gargett, South Brisbane, Australia. Source: https://www.archdaily.com/595827/new-lady-cilento-childrens-hospital-lyons-conrad-gargett

Another interesting illustration of the landscape and sustainable design approach of a modern hospital are the finalists of the international competition for the design of the largest hospital in Denmark, namely the architectural offices BIG, Herzog \& de Meuron, C. F. Møller submissions. The international competition task was to create a large-scale hospital complex Nyt Hospital Nordsjælland with a total area of about 125,000 sq.m. A picturesque plot of land was proposed for construction, which at the same time served as hunting grounds. Thus, as a context of the environment, the architects received a hilly natural landscape with the largest forest area in the country and many small lakes. Of course, as recognized world-class professionals, each of the finalist teams in their project proposals focused on the integration of nature into the arsenal of the treatment environment.

The team of the Danish office C.F. Møller proposed a project where rather high hospital buildings stand out against the surrounding landscape. The emphasized "functionality" of the project proposal of this variant of the hospital provided the concept according to which the largest hospital of the country should be deployed like the whole city with all necessary functions and structures designed for the needs of patients and staff. The center of 
the hospital complex is the pubic space with a two round in plan courtyards (Fig. 17, Fig. 18) [39].

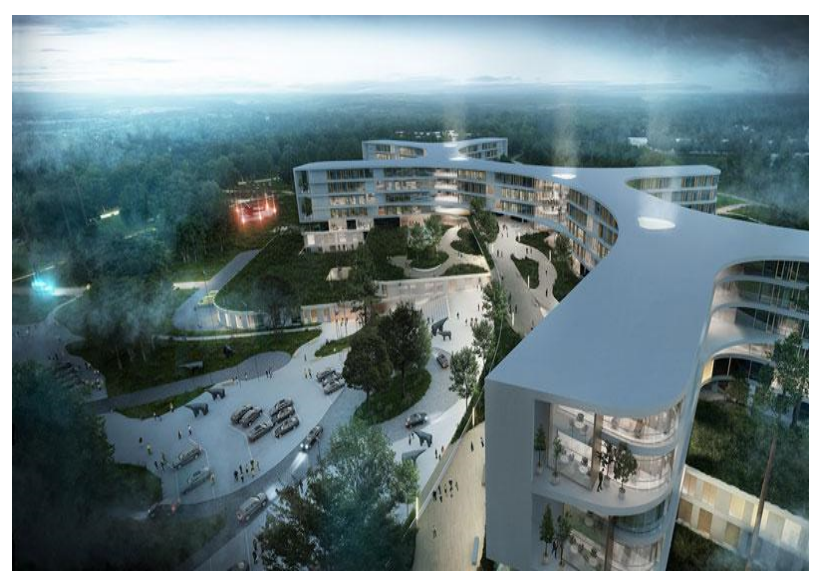

Fig. 17. General view of the Nyt Hospital Nordsjælland, C.F. Møller, Denmark. Source: https://www.cfmoller.com/p/da/Nyt-Hospital-Nordsjaelland-i-Hilleroed-i3067.html
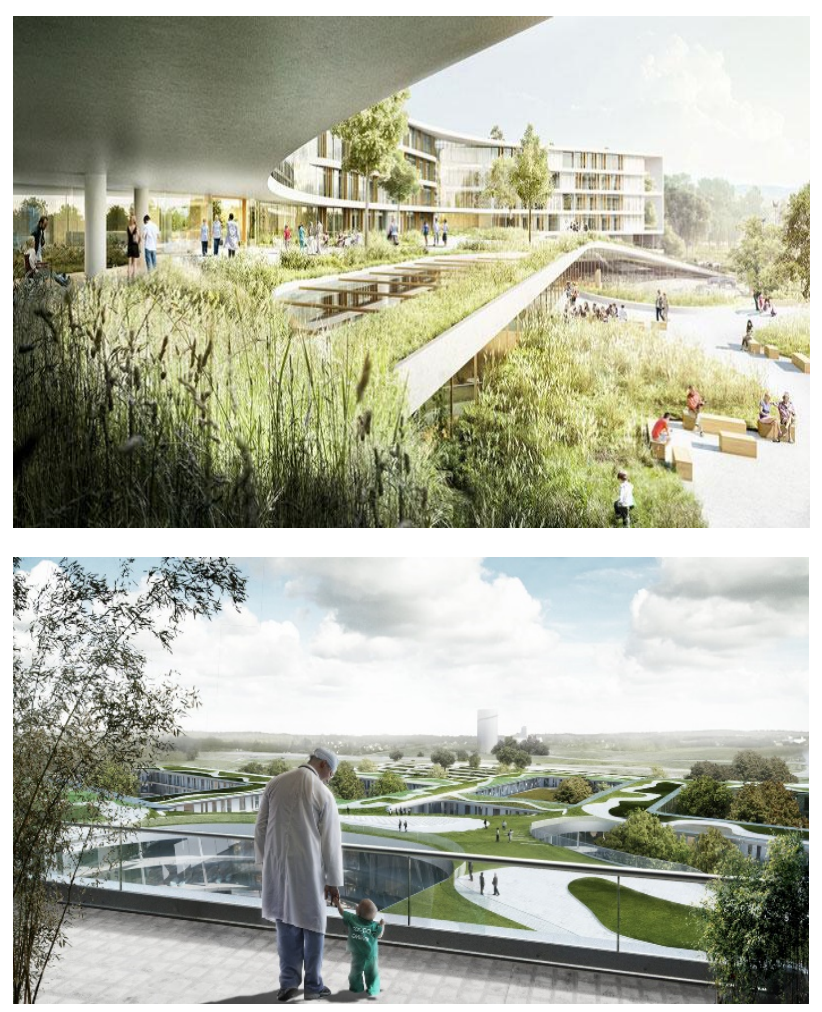

Fig. 18. General view of the Nyt Hospital Nordsjælland, C.F. Møller, Denmark. Source: https://www.earchitect.com/denmark/nyt-hospital-nordsjaelland

The design concept by the BIG architectural office is for the creation of a space capable of "healing"(Fig. 19) [40].

The shape of the hospital complex consists of eight blocks in the form of intersecting rings with courtyards. The architects explained their choice by the fact that it will guarantee a picturesque view from every chamber, the premises will be provided with sunlight, and the opportunity to go for a walk in the public garden will create the conditions for communication. Fresh air, beautiful landscapes, and a positive mood, according to the authors of the project, are true companions of fast and high-quality recovery (Fig. 20, Fig. 21) [40].

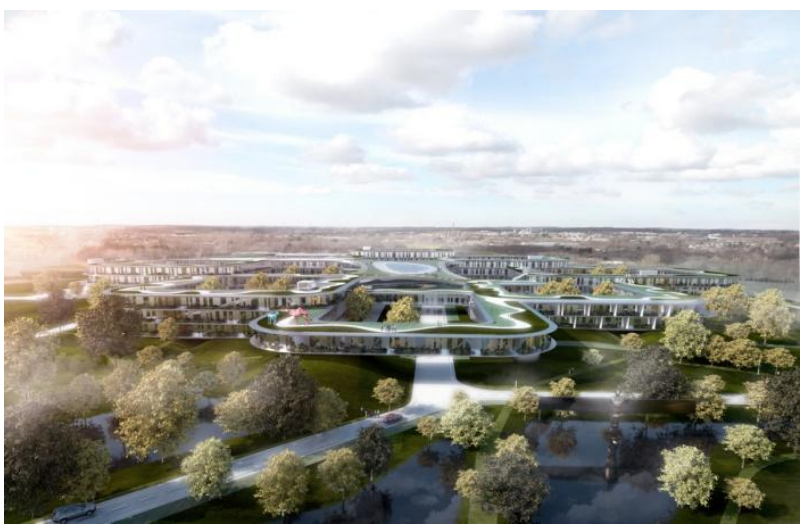

Fig. 19. General view of the Nyt Hospital Nordsjælland, BIG, Denmark. Source: https://www.archdaily.com/421002/nythospital-nordsjaelland-shortlisted-proposal-big

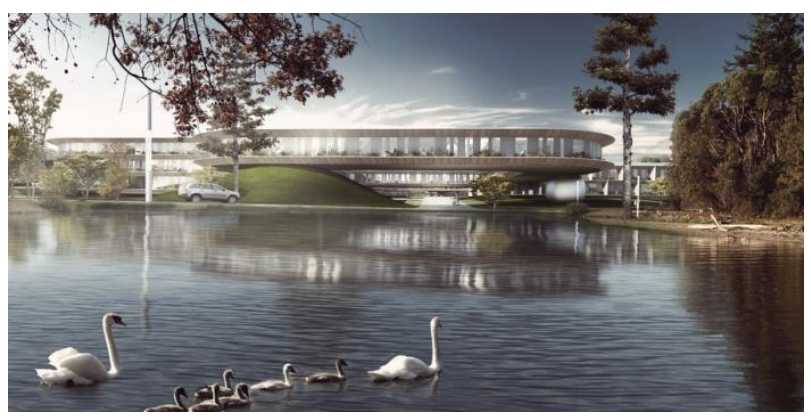

Fig. 20. General view of the Nyt Hospital Nordsjælland, BIG, Denmark. Source: https://www.archdaily.com/421002/nythospital-nordsjaelland-shortlisted-proposal-big

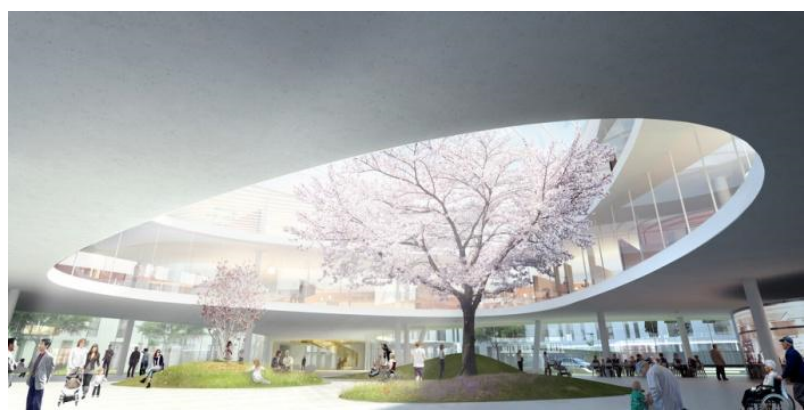

Fig. 21. Inner yard view of the Nyt Hospital Nordsjælland, BIG, Denmark. Source:

https://www.archdaily.com/421002/nyt-hospital-nordsjaellandshortlisted-proposal-big

Herzog \& de Meuron office offered two- and fourstory hospital buildings skillfully integrated into the surrounding natural landscape. The rounded lines of the building plan are more like microorganisms than the traditional shape of a hospital plan. The configuration of the hospital plan is subject to an attempt to provide maximum natural light to the wards. Intersections of hospital buildings with green roofs formed picturesque courtyards. The hospital proposal by the Herzog \& de Meuron reflects the close connection between the hospital building and the surrounding landscape, forming an 
aesthetically pleasing space of a modern hospital park (Fig. 22, Fig. 23) [40-42].

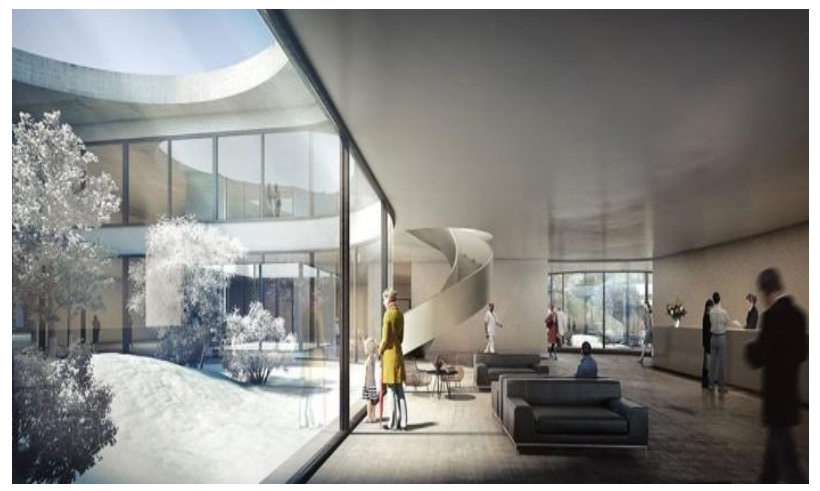

Fig. 22. Inner yard view of the Nyt Hospital Nordsjælland, Herzog \& de Meuron, Denmark. Source:

https://afasiaarchzine.com/2014/04/herzog-de-meuron_6161/

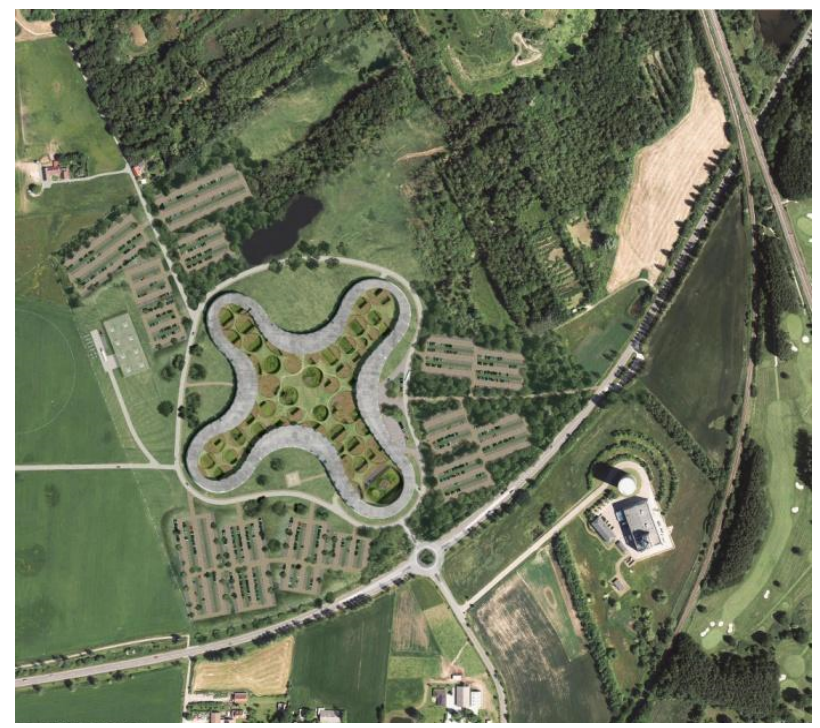

Fig. 23. Masterplan of the Nyt Hospital Nordsjælland, Herzog $\&$ de Meuron, Denmark. Source:

https://afasiaarchzine.com/2014/04/herzog-de-meuron_6161/

The idea of a park is obvious in the NTFGH and JCH hospital complex in Singapore. The architects' considerable attention to the integration of sustainable development principles into the architecture of the hospital complex has achieved incredible results. Despite the location of a large hospital in a dense urban environment with almost no free space, the hospital looks like a park with various elements of landscaping. This has significantly improved the views from the windows of hospital rooms and created an atmosphere of psychological peace, relaxation and comfort (Fig. 24, Fig. 25) [33, 34].

The Hughes Medical Institute Hospital in Virginia, USA, designed in 2008 by architect Rafael Vignoli is the best example of how the architecture can reflect the idea of hospital-park using the healing effects of the natural environment, landscape and healing power of water. G. Hughes Medical Complex performs multifunctional tasks, combining state-of-the-art medical laboratory of computational and electrophysiological examinations, robotic and technical research contains conference halls, mini-hotel, spacious public space with registration and recreation area, private offices, medical wards, etc.

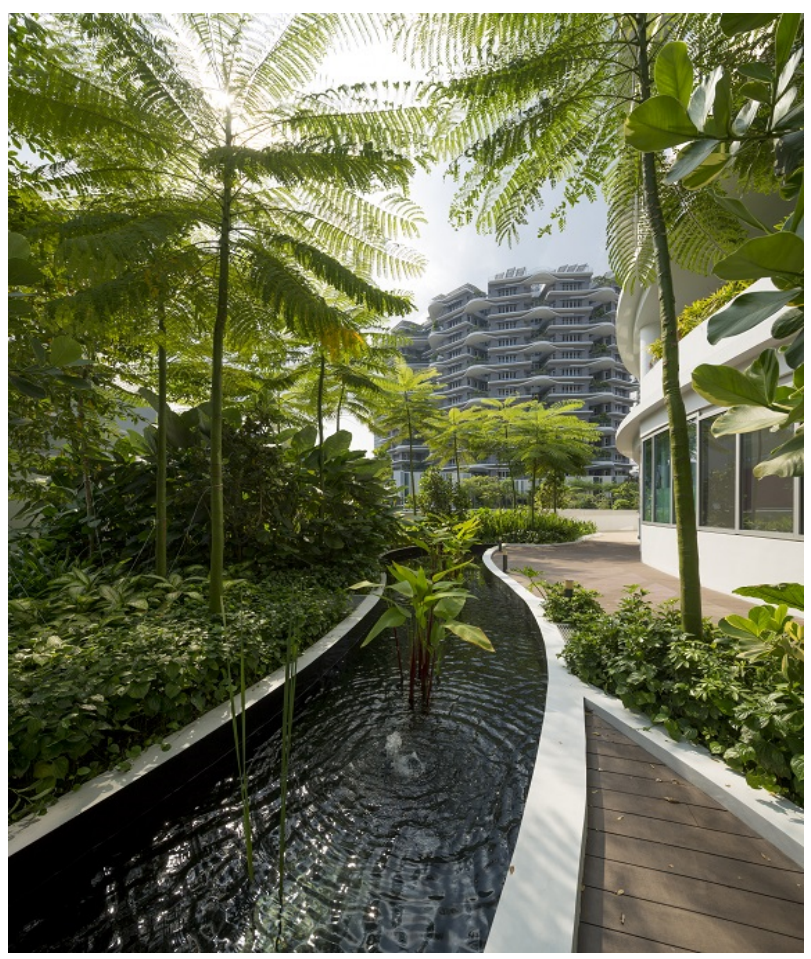

Fig. 24. Exterior and windows from the hospital complex $\mathrm{Ng}$ Teng Fong (NTFGH) \& Jurong (JCH). Source:

https:/www.wsp.com/en-MY/projects/ng-teng-fong-generalhospital-singapore

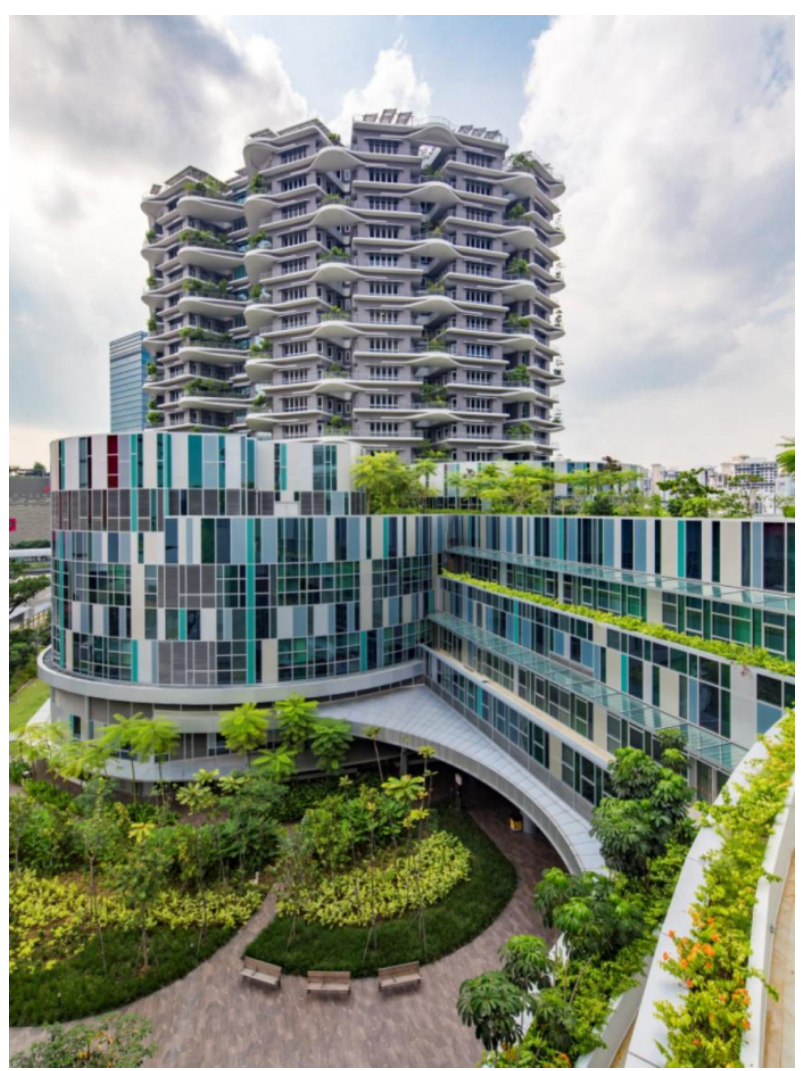

Fig. 25. Active use of landscaping in hospitals $\mathrm{Ng}$ Teng Fong (NTFGH) \& Jurong (JCH). Source: https://www.wsp.com/en$\mathrm{MY} /$ projects/ng-teng-fong-general-hospital-singapore 
The hospital stay provides short-, medium- and longterm medical research courses and programs, so the complex has a hotel for short-term treatment, as well as a building for long-term stay (Fig. 26, Fig. 27) [43-45].

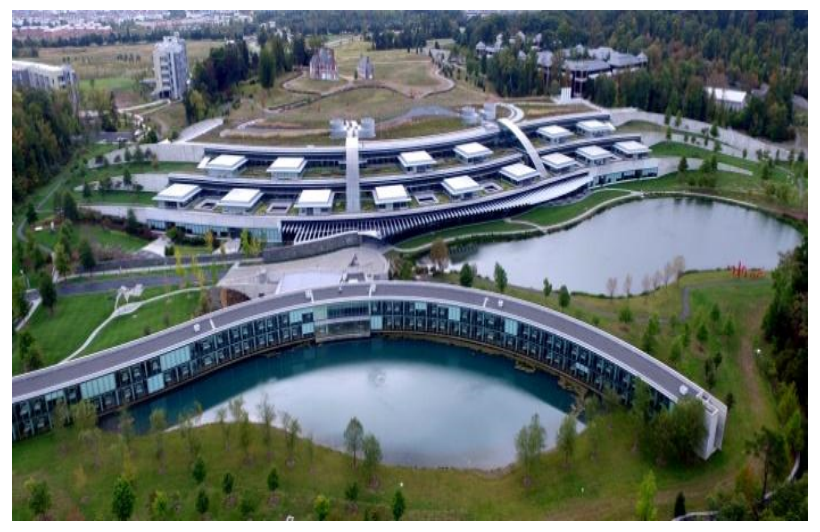

Fig. 26. General view of the Howard Hughes Medical Institute, Virginia, USA. Source: https://www.earchitect.com/america/howard-hughes-medical-institute

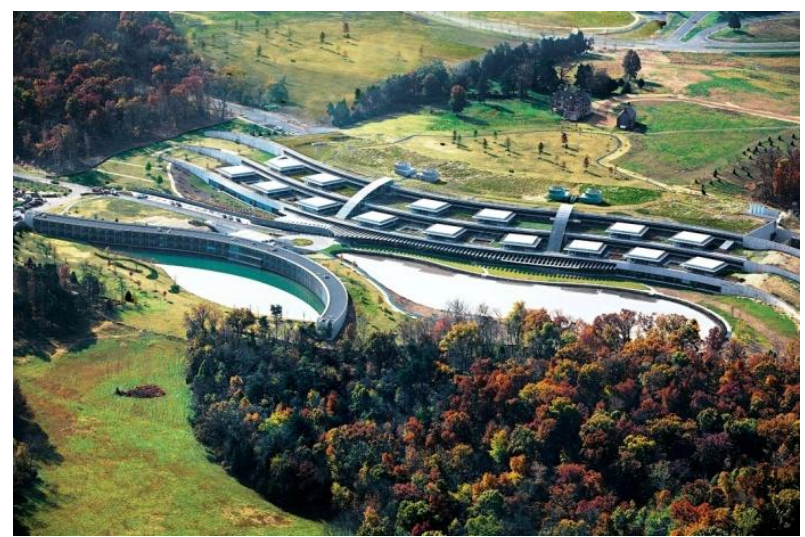

Fig. 27. General view of the Howard Hughes Medical Institute, Virginia, USA. Source: https://www.e-

architect.com/america/howard-hughes-medical-institute

The next example of the last decade health project, which shows the attention of architects to the integration of the landscape design in medical facilities and thus embodies the ideas and principles of sustainable development, is Seoul National University Hospital Medical Mall, Seoul, South Korea (Fig. 28) [46-48]. The site for the construction of the hospital is located in an urban environment with compacted buildings and has a very limited size. This prompted the bureau of Gresham Smith architects to create an innovative concept, according to which the six-story hospital building was "immersed" in the underground space. Quite a bold idea that does not correspond to the established and traditional architectural approaches to the design of health care facilities! The concept also allowed to develop another unusual tool - the arrangement of a landscape park on the released hospital territory [49].

\section{Conclusion}

Today in Ukraine there are about 1,793 hospitals with 335,835 hospital beds ( 78.5 beds per 10,000 inhabitants).
Most of these hospitals were built between the 1950s and 1980s. After construction, most of the hospitals received only minimal repairs. And only over the past five years, cosmetic repairs have begun in some hospitals located in large Ukrainian cities. Unfortunately, there is no exact informational data regarding the exact number of hospitals that have already been renovated and those that are currently being renovated.

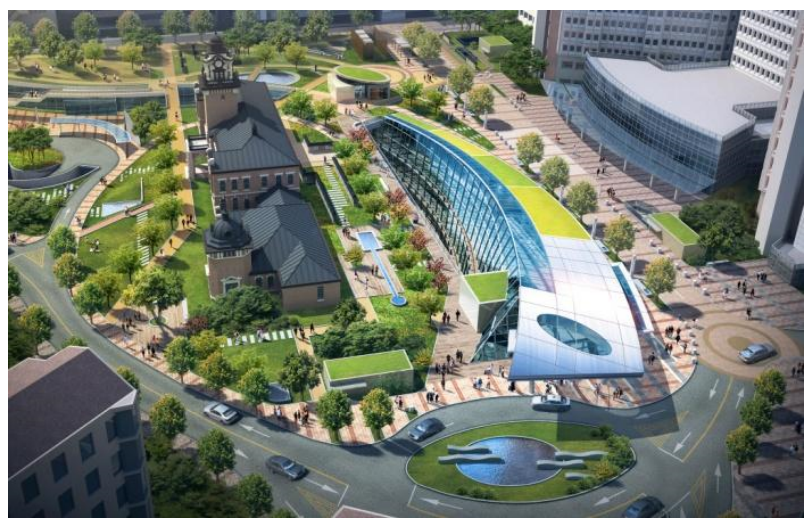

Fig. 28. General view of the Seoul National University Hospital Medical Mall, Seoul, South Korea.

Nowadays, a number of reforms are undertaken in Ukraine, one of which is to make qualitative and effective changes in the field of health care. From the author's points of view, one of the key issues that need to be addressed immediately is the introduction of ideas and principles of sustainable development in the architecture of medical institutions. From this position, the article analyzes the Ukrainian realities of the state of hospital buildings, as well as advanced foreign design and conceptual experience. Undoubtedly, a huge gap has been identified, which was formed after 30 years of ignoring the needs of modernization and development. But, despite the significant resistance of society against the reformist changes, Ukraine must pass this way. Ukrainian health care facilities must meet world standards of energysaving and energy efficiency, approaching the zero need for external network engineering systems, making the most of the regional potential of natural properties. It should be noted that it is not possible just to copy the experience of another country. There are always several diverse features (climatic, geographical, relief, hydrological, etc.), which form individual requirements and opportunities. The only invariable potential for the integration of the principles of sustainable development into the architecture of buildings designed for human health, which is appropriate and necessary to implement for all countries of the world, is the active synthesis of the medical and natural environment. One of the possible ways of realization of this idea can be designing a hospital-park, a medical institution that is inserted in a natural environment, and also contains its elements in the internal space. This approach is due to the fact that man is a part of nature, its constituent element and it is natural to assert the harmony of effective and accelerated physical and spiritual renewal in the natural environment. 


\section{References}

1. I. Bulakh, L. Kozakova, M. Didichenko, The innovative trends in architecture and urban planning of health care institutions. International Journal of Innovative Technology and Exploring Engineering 9(1), 317-323 (2019). doi:10.35940/ijitee.A4111.119119

2. University of Montreal Hospital Center (CHUM). http://healthcare.wsp-pb.com/portfolio/centrehospitalier-de-luniversite-de-montrealchum/?portfolioCats=42. Accessed 21 Mar 2021

3. CHUM. https://fondationduchum.com/. Accessed 21 Mar 2021

4. GrandEngineer. http://grandengineer.ru/grandioseprojects/camaya-bolshaya-bolnitsa-severnojameriki-stroitsya-v-monreale/. Accessed 21 Mar 2021

5. University Hospital Sant Joan de Reus, Reus, Spain. https://archello.com/es/project/university-hospitalsant-joan-de-reus. Accessed 21 Mar 2021

6. Queen Elizabeth university hospital. https:/www.arch2o.com/queen-elizabethuniversity-royal-hospital-for-children-ibi-group/. Accessed 21 Mar 2021

7. The UAE plans to create a hospital in space with nanorobots. https:/earth-chronicles.com/science/theuae-plans-to-create-a-hospital-in-space-withnanorobots.html. Accessed 21 Mar 2021

8. Space clinic being developed to treat Emirati astronauts.

https://www.thenational.ae/uae/health/space-clinicbeing-developed-to-treat-emirati-astronauts1.700621. Accessed 21 Mar 2021

9. The UAE is building a hospital in space. https://steemit.com/space360/@khorsi/the-uae-isbuilding-a-hospital-in-space. Accessed 21 Mar 2021

10. Cleveland Clinic Abu Dhabi. hospital in space. https://www.archdaily.com/292167/in-progresscleveland-clinic-abu-dhabi-hdr-architecture. Accessed 21 Mar 2021

11. Rating of the countries of the world by level of healthcare in 2018. https://www.bloomberg.com/news/articles/2018-0919/u-s-near-bottom-of-health-index-hong-kong-andsingapore-at-top. Accessed 21 Mar 2021

12. Y. Tabunschikov, M. Brodach, N. Shilkin, Energyefficient high-rise building 3, 8 (2002)

13. Y. Tabunschikov. Mathematical models of thermal conditions in buildings (CRC Press, 1993)

14. Y. Tabunschikov, M. Brodach, Scientific principles of designing energy-efficient buildings. ABOK 1 (2008)

15. A. Holstov, G. Farmer, B. Bridgens, Sustainable Materialisation of Responsive Architecture. Sustainability 9, 435 (2017). doi:10.3390/su9030435

16. H. Salleh, N. A. Mohamed Sabli, A. Shah Ali, M. Alshawi, Performance Evaluation for IT/IS
Implementation in Organisation: Preliminary New IT/IS Capability Evaluation (NICE) Model. Journal of Design and the Built Environment 9(1), 75-88 (2011)

17. M. A. Bengochea Escribano, P. A. López Jiménez, G. López Patiño, M. Mora Pérez, Cuantificación de la eficiencia de la fachada cerámica ventilada mediante técnicas de la mecánica de fluidos computacional, Boletín de la Sociedad Española de Cerámica y Vidrio 50(2), 99-108 (2011). doi:10.3989/cyv.142011

18. R. Loonen, A. Khairulina, J. Hensen, Bioadaptive shell of buildings. High-tech buildings 3(3-3), 50-57 (2014)

19. S. Reichert, A. Menges, D. Correa, Meteorosensitive Architecture: Biomimetic Building Skins Based on Materially Embedded and Hygroscopically Enabled Responsiveness. Computer-Aided Design 60, 50-59 (2015). doi:10.1016/j.cad.2014.02.010

20. B. D. Hatton, I. Wheeldon, M. J. Hancock, M. Kolle, J. Aizenberg, D. B. Ingber, An Artificial Vasculature for Adaptive Thermal Control of Windows, Solar Energy Materials and Solar Cells 117, 429-436 (2013) doi:10.1016/j.solmat.2013.06.027

21. Now or Never: IEA Energy Technology Perspectives 2008 shows pathways to sustained economic growth based on clean and affordable energy technology. https://www.iea.org. Accessed 21 Mar 2021

22. Energy saving by adding a glass-façade to a brick building.

https://www.lunduniversity.lu.se/lup/publication/e3 918b4c-7f6c-4fd7-8c42-da9ac8e94c71

23. G. Kovalska, I. Merylova, I. Bulakh, Urban improvement of comprehensive schools and out of school educational establishments in Ukraine. International Journal of Innovative Technology and Exploring Engineering 8(12), 1765-1770 (2019). doi:10.35940/ijitee.L3229.1081219

24. S. Semerikov, S. Chukharev, S. Sakhno, A. Striuk, V. Osadchyi, V. Solovieva, H. Danylchuk, Our sustainable coronavirus future. E3S Web of Conferences 166, $00001 \quad$ (2020). doi:10.1051/e3sconf/202016600001

25. A. Wierzbicka, E. Pedersen, R. Persson, B. Nordquist, K. Stålne, C. Gao, Healthy Indoor Environments: The Need for a Holistic Approach. International Journal of Environmental Research and Public Health 15(9), $1874 \quad$ (2018). doi:10.3390/ijerph15091874

26. K. Ren, L. $\mathrm{Xu}$, Dataset on energy efficiency assessment and measurement method for childfriendly space in cold residential area. Data in Brief 14(C), 148-155 doi:10.1016/j.dib.2017.07.032

(2017).

27. J. A. Fadamiro, J. A. Adedeji, An overview of collapse of buildings in Nigeria: a medico-spatial analysis. Journal of Architecture and Built Environment 40(2), 53-62 (2013) 
28. M. F. S. Van der Ham, S. Zlatanova, E. Verbree, R. Voûte, Real time localization of assets in hospitals using quuppa indoor positioning technology. Remote Sensing and Spatial Information Sciences IV-4/W1, 105-110 (2016). doi:10.5194/isprs-annals-IV-4-W1$105-2016$

29. M. Spikman, D. Van Dijk, Comparison of the energy performance of buildings in the EU. Energy saving 5, 43-45 (2009)

30. R. C. G. M. Loonen, M. Trčka, D. Costola, J. L. M. Hensen, Climate Adaptive Building Shells: State of the Art and Future Challenges. Renewable and Sustainable Energy Reviews 25, 483-493 (2013). doi:10.1016/j.rser.2013.04.016

31. The Centre for Health Design. https://www.healthdesign.org. Accessed 21 Mar 2021

32. I.V. Bulakh, Urban Planning Organization and Development of Children's Medical Institutions in Ukraine. Journal of Regional and City Planning. Bandung 31(1), 82-96 (2020). doi:10.5614/jpwk.2020.31.1.6

33. NG TENG FONG general hospital and JURONG community hospital, Singapore. https://www.wsp.com/en-CN/projects/ng-teng-fonggeneral-hospital-singapore. Accessed 21 Mar 2021

34. Ng Teng Fong General Hospital. https://aasarchitecture.com/2017/09/aia-coteselected-ng-teng-fong-general-hospital-sustainabledesign-excellence-

2017.html/?:+AAsArchitecture+(A+As+Architectur e). Accessed 21 Mar 2021

35. I. Bulakh, M. Didichenko, O. Kozakova, O. Chala, Sustainable futures in the context of architectural design of hospitals. E3S Web of Conferences 166, 08001 (2020). doi:10.1051/e3sconf/202016608001

36. I. V. Bulakh, Artistic and Aesthetic Formation and Evolution of Architectural and Urban Planning Space. Science and Innovation 15(5), 57-66 (2019). doi:10.15407/scine15.05.057

37. 2016 National Landscape Architecture Awards: Award of Excellence for Civic Landscape. https://architectureau.com/articles/2016-nationallandscape-architecture-awards-award-of-excellencefor-civic-landscape/\#. Accessed 21 Mar 2021

38. New Lady Cilento Children's Hospital / Lyons + Conrad https://www.archdaily.com/595827/new-ladycilento-children-s-hospital-lyons-conrad-gargett. Accessed 21 Mar 2021

39. New North Zealand Hospital by C.F. Møller. https://design-chronicle.com/new-north-zealandhospital-by-c-f-moller/. Accessed 21 Mar 2021

40. Nyt Hospital Nordsjælland. Design: BIG. https://www.e-architect.co.uk/denmark/nyt-hospitalnordsjaelland. Accessed 21 Mar 2021

41. Herzog \& de Meuron to Design One of Denmark's Largest Hospitals. https://www.archdaily.com/495113/herzog-and-demeuron-to-design-one-of-denmark-s-largesthospitals. Accessed 21 Mar 2021

42. Top names for Nyt Hospital Nordsjælland. https:/www.worldarchitecturenews.com/article/151 3464/top-names-nyt-hospital-nordsjalland. Accessed 21 Mar 2021

43. Press Room. https://www.hhmi.org/press-room. Accessed 21 Mar 2021

44. Howard Hughes Medical Institute Virginia: Building. https://www.earchitect.co.uk/america/howard-hughes-medicalinstitute. Accessed 21 Mar 2021

45. Howard Hughes Medical Institute, Janelia Farm Research Campus. https://www.austriaarchitects.com/es/projects/view/howard-hughesmedical-institute-janelia-farm-research-campus. Accessed 21 Mar 2021

46. Seoul National University Hospital Medical Mall, Seoul, South Korea. http://architect1.blogspot.com/2016/01/seoul-national-universityhospital-Mall.html. Accessed 21 Mar 2021

47. Growing a Hospital from the Ground Down: Seoul National University Hospital Medical Mall. https://www.greshamsmith.com/project/seoulnational-university-hospital-medical-mall/. Accessed 21 Mar 2021

48. Seoul National University Hospital Medical Mall, Seoul, South Korea. http://www.mooyoung.com/eng/board/project/board _view.asp?num=1296. Accessed 21 Mar 2021

49. N. Shebek, V. Timokhin, Y. Tretiak, I. Kolmakov \& O. Olkhovets, Sustainable development and harmonization of the architectural environment of cities. E3S Web of Conferences 166, 09001 (2020). doi:10.1051/e3sconf/202016609001 